\title{
Peningkatan Produksi Asam Glutamat Corynebacterium glutamicum dengan Penambahan Penisilin pada Fase Logaritmik
}

\section{Effects of Penicillin Treatment on Incubation Periods to Glutamic Acid Production by Corynebacterium glutamicum IFO 12168}

\author{
Exsyupransia Mursyanti ${ }^{*}$ dan Sri Lestari $^{1}$
}

Fakultas Biologi, Universitas Atma Jaya Yogyakarta, Jl. Babarsari 44, Yogyakarta, 55281, Indonesia. E-mail: Santi_em@mail.uajy.ac.id *Penulis untuk korespondensi

\begin{abstract}
One way to increase production and excretion of glutamic acid was to increase cell's permeability. Penicillin has a potency to change the cell permeability by inhibitng cell wall synthesis. However, penicillin treatment was effective only for actively dividing cells. Therefore, such a research was done to study on the time of penicillin treatment to the medium, so that it can be found optimal cell biomass to produce maximum glutamic acid. The cell utilized in the research was Corynebacterium glutamicum IFO 12168 that was in batch cultured. Concentration of penicillin added was 5 unit/ml and treated at incubation periods 12, 14, 16, 18, and 20 hours, respectively, after inoculation. The steps of the research were as follows purification test, growth pattern, and glutamic acid production. Parameters measured at the end of the fermentation were cell biomass, reduced sugar concentration, medium's $\mathrm{pH}$, and glutamic acid concentration. Data was analysed utilizing Anova and the significant difference between treatments were tested using Duncan's Multiple Range Test (DMRT). The growh pattern shown that logarithmic phase was reached at 2 to 22 hrs of incubation periods, therefore the treatment of penicillin was given at 12, 14, 16, 18, and $20 \mathrm{hrs}$ of incubation periods. Cell biomass produced was corelate with the concentration of reduced sugar in the medium. Measured $\mathrm{pH}$ of the medium at the end of the fermentation was on the $\mathrm{pH}$ range for the growth of $\mathrm{C}$. glutanicum. The research concluded that Penicillin treatment was able to increase significantly the glutamic acid production compatred to control treatment. Time accuracy of penicillin treatment to produce maximum glutamic acid $(154319,60 \mu \mathrm{g} / \mathrm{ml})$ was on $18 \mathrm{hrs}$ of incubation period.
\end{abstract}

Key words: glutamic acid, Corynebacterium glutamicum, penicillin treatment

Diterima: 11 Februari 2005, disetujui: 02 Maret 2005

\section{Pendahuluan}

Penggunaan asam glutamat secara komersial oleh industri makanan, kesehatan, dan industri kimia mengalami peningkatan Oleh karena itu perlu usaha untuk meningkatkan produksi asam glutamat. Jenis bakteri yang secara luas digunakan untuk produksi asam glutamat adalah Corynebacterium glutamicum (Hoischen dan Kramer, 1990).
Menurut Crueger and Crueger (1990), Corynebacterium dapat menghasilkan asam glutamat dalam jumlah yang lebih besar dibandingkan mikrobia penghasil asam glutamat yang lainnya. Produksinya akan maksimal pada pH 7,0-8,0 (Prescot dan Dunn, 1959) dan suhu 30-35 ${ }^{\circ} \mathrm{C}$ (Wibowo, 1989). Menurut Schlegel dan Karin (1994), suhu inkubasi $30{ }^{\circ} \mathrm{C}$ dan waktu inkubasi 40 jam dapat menghasilkan asam glutamat sebesar 50 $\mathrm{g} / \mathrm{l}$. 
Beberapa cara yang dapat dilakukan untuk meningkatkan sekresi asam glutamat yaitu pemberiaan biotin secara terbatas (Shiio et al., 1962), penambahan derivatif asam lemak spesifik (Takinami et al., 1965), penambahan penisilin (Nunheimer et el.,1970) atau fermentasi menggunakan auksotrof asam oleat (Kitano et al., 1972) atau auksotrof gliserol (Nakao et al., 1972). Semua cara diatas mengakibatkan adanya perubahan pada membran bakteri (Hoischen dan Kramer, 1990). Menurut Blanch et al. (1985), permeabilitas dinding sel merupakan faktor penting dalam produksi asam glutamat.

Untuk meningkatkan permeabilitas dinding sel sehingga produksi asam glutamat meningkat yaitu dengan penambahan penisilin selama pertumbuhan logaritmik. (Crueger and Crueger, 1990). Hanya saja efek penisilin yang menghambat sintesis dinding sel terbatas pada sel yang aktif membelah. Fokus makalah ini adalah pengaruh waktu pemberian penisilin terhadap produksi asam glutamat.

Menurut Crueger and Crueger (1990), penisilin dapat ditambahkan pada saat fase logaritmik yaitu sekitar 8-12 jam setelah inokulasi bakteri pada medium fermentasi. Menurut Hong et al. (1984), penambahan penisilin sebanyak 5 units/ml akan dihasilkan konsentrasi asam glutamat sebesar 90,8 g/L. Oleh karena itu pada penelitian ini kadar penisilin yang digunakan adalah 5 units $/ \mathrm{ml}$ dan ditambahkan ke dalam kultur pada fase logaritmik. Untuk itu perlu dikaji waktu terjadinya fase logaritmik $C$ glutamicum pada kultur sekali unduh sehingga dapat diketahui waktu yang tepat (pada fase logaritmik) dalam penambahan penisilin ke dalam kultur untuk menghasilkan asam glutamat maksimal.

\section{Metode Penelitian}

\section{Sistem Kultur dan Rancangan Percobaan}

Isolat kultur yang digunakan dalam penelitian ini adalah Corynebacterium glutamicum IFO 12168 (PAU Pangan dan Gizi, UGM), sedangkan sistem kultur yang digunakan adalah batch culture. Penisilin sebesar 5 unit/ml ditambahkan ke medium pada variasi waktu inkubasi, yaitu 12 jam, 14 jam, 16 jam, 18 jam, dan 20 jam setelah inokulasi. Rancangan percobaan yang digunakan adalah Rancangan Acak Lengkap (RAL) dengan tiga ulangan (Zar, 1996).

\section{Tahapan Penelitian dan Parameter yang diukur}

Tahap penelitian yang dilakukan yaitu persiapan medium, karakterisasi isolat kultur (Jutono dkk., 1980), pembuatan kultur kerja Corynebacterium glutamicum, pembuatan starter Corynebacterium glutamicum, pengukuran kurva pertumbuhan, pengukuran kadar gula reduksi, pengukuran kadar asam glutamat, pengukuran $\mathrm{pH}$, pengukuran jumlah biomassa sel.

Komposisi medium yang digunakan glukosa $40 \mathrm{~g}, \mathrm{~K}_{2} \mathrm{HPO}_{4} 1,0 \mathrm{~g}, \mathrm{MgSO}_{4} .7 \mathrm{H}_{2} \mathrm{O} 0,5$ $\mathrm{g}$, yeast ekstrak 1,0 g, Urea $8 \mathrm{~g}$. Karakterisasi yang dilakukan meliputi pengecatan gram, uji katalase, dan uji motilitas. Inkubasi dilakukan di dalam shaker selama 24 jam dengan suhu 30 ${ }^{0} \mathrm{C}$.

Pertumbuhan diukur dengan metode turbidimetri menggunakan spektrofotometer pada panjang gelombang $620 \mathrm{~nm}$ setiap dua jam selama 24 jam inkubasi. Pengukuran Gula reduksi dengan metode DNS (Kartika, 1990), sedangkan pengukuran kadar asam glutamate menggunakan High Performance Liquid Chromatography (HPLC) dengan metode analisis Ortho phethaldialdehyde (OPA) pada setiap sampel. Perhitungan kadar asam amino berdasarkan luas puncak. Kondisi HPLC yang digunakan suhu kolom $27{ }^{\circ} \mathrm{C}$ (suhu kamar), laju aliran fase mobil : $0,5 \mathrm{ml} / \mathrm{menit}$, detektor Fluoresensi, Kolom C18, Eluen (fase mobil) berupa reagen A dan B dengan sistem gradien. Biomasa sel diukur berdasarkan berat kering sel pada setiap perlakuan setelah 72 jam inkubasi.

\section{Analisis Data}

Data penelitian yang akan diperoleh kemudian dianalisis dengan uji ANAVA dengan tingkat kepercayaan 95\%, apabila hasil uji ANAVA menunjukkan beda nyata maka dilakukan uji Duncan's Multiple Range Test 
(DMRT) untuk mengetahui beda nyata antara perlakuan.

\section{Hasil dan Pembahasan}

\section{Karakterisasi $C$. glutamicum}

Karakterisasi terhadap C. Glutamicum IFO 12168 yang digunakan untuk penelitian ini seperti yang disajikan pada Tabel 1 .

Sifat-sifat seperti yang terdapat pada Tabel 1 sesuai dengan ciri-ciri umum Corynebacterium glutamicum yang disampaikan oleh Breed et al. (1957). Warna biru dari hasil pengecatan gram menunjukkan bahwa $C$ glutamicum bersifat Gram positif.

\section{Pola Pertumbuhan C. glutamicum IFO 12168 pada medium}

Penelitian terhadap pola pertumbuhan $C$ glutamicum pada medium dengan sistem kultur sekali unduh (batch culture) perlu dilakukan untuk mengetahui waktu terjadinya fase logaritmik. Menurut Crueger and Crueger (1990), penisilin dapat meningkatkan produksi asam glutamat apabila ditambahkan ke dalam kultur pada fase logaritmik.

Tabel 1. Morfologi dan sifat biokimia C. Glutamicum IFO 12168

\begin{tabular}{|c|c|c|}
\hline No. & Karakter & Keterangan \\
\hline 1. & Bentuk sel & Batang agak melengkung \\
\hline 2. & Bentuk koloni & Sirkuler, tepi koloni bertipe entire, elevasi bertipe raised \\
\hline 3. & Warna koloni & putih \\
\hline 4. & Pengecatan Gram & Gram positif (berwarna biru) \\
\hline 5. & Uji katalase & Positif dengan membentuk gelembung \\
\hline 6. & Uji motilitas & Non motil \\
\hline \multirow[t]{5}{*}{7.} & Uji Biokimia & \\
\hline & a. Glukosa & $\begin{array}{l}\text { Positif, terjadi perubahan warna medium dari merah menjadi kuning } \\
\text { tetapi tidak terbentuk gas }\end{array}$ \\
\hline & b. Laktosa & $\begin{array}{l}\text { Positif, terjadi perubahan warna medium dari merah menjadi kuning } \\
\text { tetapi tidak terbentuk gas }\end{array}$ \\
\hline & c. Sukrosa & Positif, terjadi perubahan warna medium tetapi tidak terbentuk gas \\
\hline & d. Nitrat & Positif, mengubah nitrat menjadi nitrit \\
\hline
\end{tabular}

Pola pertumbuhan bakteri pada kultur sekali unduh akan memperlihatkan empat fase pertumbuhan utama, yaitu fase adaptasi (fase lag), fase eksponensial (fase logaritmik), fase stasioner dan fase kematian (Crueger and Crueger, 1990). Penelitian yang dilakukan terhadap pola pertumbuhan $C$ glutamicum pada medium sekali unduh juga menunjukkan ke-4 fase pertumbuhan utama, yaitu fase adaptasi yang berlangsung dari awal inokulasi sampai jam ke-2, dilanjutkan fase logaritmik sampai waktu inkubasi jam ke-22, fase stasioner terjadi pada jam ke 22 sampai jam ke-30 selanjutnya
C. glutamicum memasuki fase kematian (Gambar 1). Oleh karena fase logaritmik terjadi pada inkubasi jam ke-2 sampai ke 22 maka waktu penambahan penisilin dipilih pada jam ke 12, 14, 16, 18 dan 20. Variasi waktu penambahan penisilin dilakukan untuk mendapatkan jumlah dan kondisi fisiologis sel maupun kondisi medium kultur yang optimal sehingga dengan adanya penambahan penisilin, kultur bakteri dapat mensekresikan asam glutamat secara maksimal. 


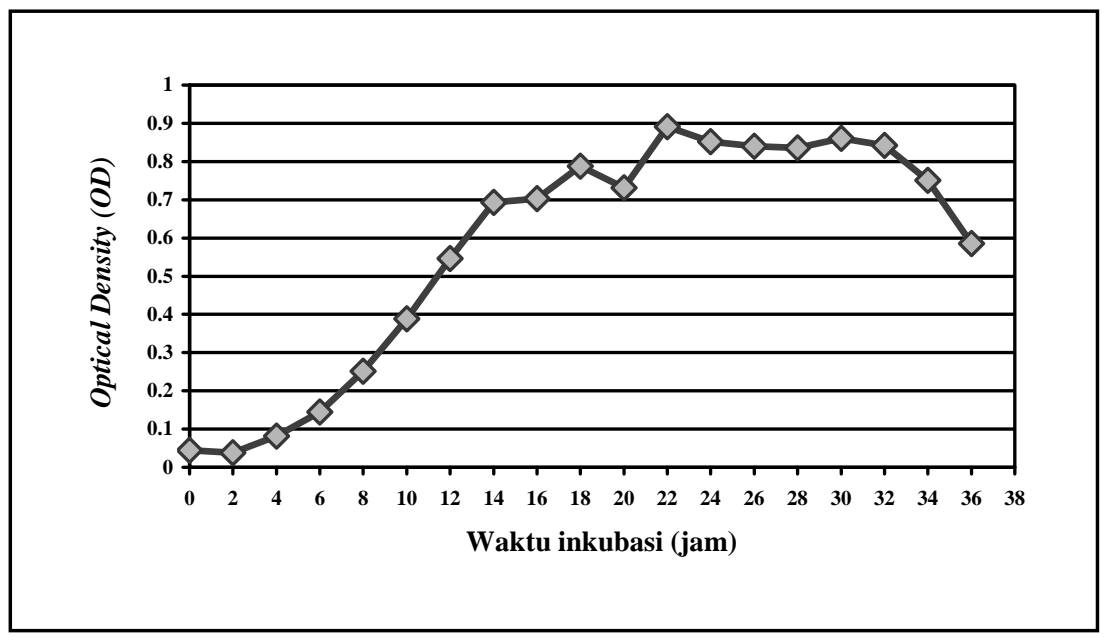

Gambar 1. Pola pertumbuhan C. Glutamicum IFO 12168 pada medium fermentasi selama 38 jam inkubasi.

Pengaruh Penambahan Penisilin pada Medium terhadap Biomasa sel $C$. glutamicum IFO 12168, Kadar gula reduksi, nilai pH dan kadar asam glutamat

Penisilin yang ditambahkan ke dalam kultur adalah sebanyak 5 unit/ml dan ditambahkan sesuai dengan perlakuan waktu penambahan penisilin. Berdasarkan analisis kuantitatif yang dilakukan diakhir proses fermentasi (inkubasi selama 72 jam) terhadap biomasa sel yang berdasarkan pada berat kering sel, kadar gula reduksi yang masih terdapat pada medium, $\mathrm{pH}$ akhir medium dan kadar asam glutamat yang diproduksi, menghasilkan data yang dapat dilihat pada Tabel 2 dan secara skematis dapat dilihat pada Gambar 2.

Tabel 2. Pengaruh waktu penambahan penisilin terhadap biomasa sel, kadar gula reduksi, $\mathrm{pH}$ dan kadar asam glutamat kultur $C$ glutamicum IFO 12168 umur 72 jam inkubasi.

\begin{tabular}{ccccc}
\hline \hline $\begin{array}{c}\text { Waktu penambahan } \\
\text { pinisilin }(\mathrm{jam})\end{array}$ & $\begin{array}{c}\text { Biomasa sel } \\
(\mathrm{mg} / \mathrm{ml} \mathrm{b.k})^{*}\end{array}$ & $\begin{array}{c}\text { Kadar gula reduksi } \\
(\mathrm{mg} / \mathrm{ml})\end{array}$ & $\mathrm{pH}^{* *}$ & $\begin{array}{c}\text { Kadar asam glutamat } \\
(\mu \mathrm{g} / \mathrm{ml})\end{array}$ \\
\hline \hline Kontrol & $86,97 \mathrm{a}$ & $57,77 \mathrm{~d}$ & $7,47 \mathrm{~g}$ & $9.383,60 \mathrm{k}$ \\
12 & $95,87 \mathrm{~b}$ & $40,63 \mathrm{ef}$ & $7,12 \mathrm{~h}$ & $72.831,00 \mathrm{kl}$ \\
14 & $83,30 \mathrm{a}$ & $43,47 \mathrm{f}$ & $7,12 \mathrm{~h}$ & $85.489,94 \mathrm{kl}$ \\
16 & $109,17 \mathrm{c}$ & $38,37 \mathrm{e}$ & $7,39 \mathrm{i}$ & $83.124,42 \mathrm{kl}$ \\
18 & $101,50 \mathrm{~b}$ & $41,93 \mathrm{ef}$ & $7,33 \mathrm{j}$ & $154.319,601$ \\
20 & $112,40 \mathrm{c}$ & $40,07 \mathrm{ef}$ & $7,35 \mathrm{ij}$ & $78.847,75 \mathrm{k}$ \\
\hline \hline
\end{tabular}

Keterangan : * b.k.= berat kering

** pengukuran $\mathrm{pH}$ dilakukan diakhir fermentasi (72 jam inkubasi, $\mathrm{pH}$ awal semua perlakuan sama yaitu 7,8 )

Penambahan penisilin pada medium mempengaruhi pertumbuhan sel dalam populasi, hal ini dapat dilihat pada perlakuan penambahan penisilin pada jam inkubasi ke 12, 16, 18 dan 20 yang menghasilkan biomasa yang jauh lebih besar dan berbeda secara signifikan dengan kontrol (tanpa penambahan penisilin). Jumlah biomasa yang terbesar ditemukan pada perlakuan penambahan penisilin pada waktu inkubasi jam ke 20. Hasil 
ini menunjukkan penambahan penisilin sebanyak 5 unit/ml pada fase logaritmik belum bersifat toksik bagi pertumbuhan sel, bahkan bersifat memacu pertumbuhan sel.

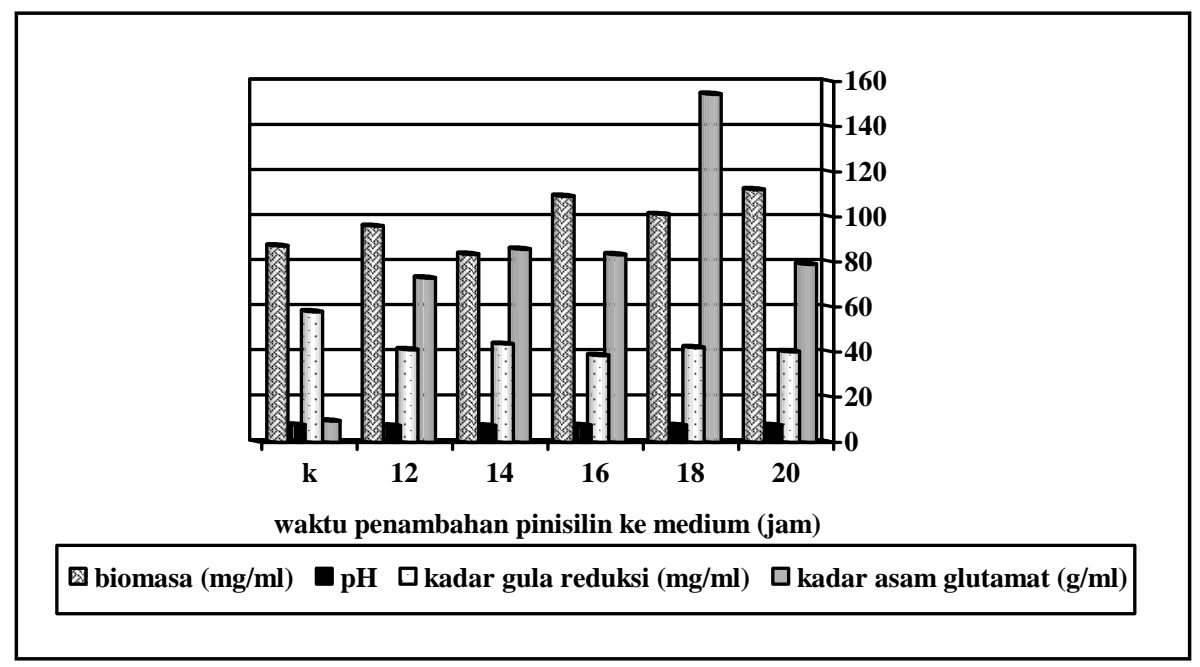

Gambar 2. Pengaruh waktu penambahan penisilin terhadap biomasa sel, kadar gula reduksi, pH dan kadar asam glutamat kultur $C$ glutamicum IFO 12168 waktu inkubasi $72 \mathrm{jam}$.

Apabila dilihat pada pola pertumbuhan C. glutamicum (Gambar 1), jam inkubasi ke 20 berada pada fase logaritmik akhir dimana selsel mempunyai aktivitas pembelahan mendekati maksimum. Apabila dalam kondisi ini ditambahkan penisilin maka jumlah sel sudah mencapai maksimum sehingga efek penisilin hanya mempengaruhi permeabilitas membran. Menurut Tortora et al. (2001), target penisilin adalah pada proses sintesis dinding sel pada sel yang aktif melakukan pertumbuhan. Senyawa ini akan menghambat sistesis peptidoglikan dan memperlemah struktur dinding sel. Kondisi ini akan meningkatkan permeabilitas dinding sel bakteri (Crueger and Crueger, 1989).

Hasil pengukuran kadar gula reduksi yang masih terdapat dalam medium menunjukkan hasil yang sesuai dengan jumlah biomasa sel pada setiap perlakuan. Semakin tinggi biomasa sel maka gula reduksi yang digunakan semakin banyak sehingga gula yang tidak terpakai dan masih tersisa dalam medium semakin sedikit. Pada penelitian ini bentuk gula yang digunakan sebagai sumber $\mathrm{C}$ dan energi adalah glukosa. Menurut Stryer (1995), glukosa adalah bentuk karbohidrat yang siap pakai sebagai sumber $\mathrm{C}$ dan energi untuk pertumbuhan karena langsung dapat memasuki jalur glikolisis. Penggunaan glukosa oleh $C$. glutamicum yang diberi perlakuan penisilin jauh lebih besar dibanding dengan kontrol.

Derajat keasaman $(\mathrm{pH})$ medium diakhir fermentasi (72 jam inkubasi) masih dalam kisaran $\mathrm{pH}$ optimum untuk pertumbuhan $C$. glutamicum, yaitu pada kisaran 7-8. Menurut Crueger and Crueger (1990), medium produksi asam glutamat sebaiknya diset 8,5 dengan penambahan amonia selanjutnya secara otomatis akan dijaga pada $\mathrm{pH}$ 7,8 selama proses fermentasi. Hasil penelitian $\mathrm{pH}$ pada semua perlakuan menunjukkan kondisi yang lebih asam. Hasil ini kemungkinan disebabkan oleh sistem batch culture yang digunakan sangat sederhana, yaitu sekali unduh tanpa dilakukan kontrol $\mathrm{pH}$ selama proses fermentasi berlangsung. Selain itu kemungkinan adalah waktu pemanenan 72 jam inkubasi yang menyebabkan sel-sel dalam fase kematian. Menurut Tortora et al (2001), fase kematian ditandai dengan banyak sel yang lisis. Kondisi ini menyebabkan banyak komponen sel yang tercampur dengan medium dan mempengaruhi keasaman medium.

Pada bakteri penghasil asam glutamat, termasuk C. Glutamicum, asam glutamat disintesis dari asam $\alpha$-ketoglutarat, amonia dan Diphospopyridine nukleotide (DPNH) 
(Winarno dan Fardiaz, 1979). Penisilin tidak akan mengganggu jalur sintesis ini tetapi akan mengganggu sintesis dinding sel.

Kadar asam glutamat yang dihasilkan pada perlakuan kontrol dengan perlakuan panambahan penisilin berbeda secara signifikan. Penambahan penisilin mampu meningkatkan produksi asam glutamat $C$. glutamicum secara signifikan. Pada penelitian ini penisilin yang ditambahkan ke dalam medium sebanyak 5 unit/ml sehingga perlu dikaji kembali kadar penisilin yang optimum yang perlu ditambahkan sehingga produksi asam glutamat dapat maksimal.

Penisilin yang ditambahkan pada fase logaritmik akan memacu ekskresi dari asam glutamat. Penisilin ini akan menurunkan kecepatan pertumbuhan dengan cara menghambat sintesis peptidoglikan sebagai komponen utama (90\%) pembentuk dinding sel bakteri gram positif (Madigan et al., 2000). Menurut Crueger and Crueger (1990), penggunaan penisilin untuk produksi komersial asam glutamat bisa diterapkan dengan menggunakan medium limbah, misalnya menggunakan molase. Sebenarnya molase tidak dapat digunakan sebagai substrat untuk produksi asam glutamat karena kandungan biotinnya tinggi. Biotin dapat menghambat sekresi asam glutamat. Oleh karena itu, penisilin yang ditambahkan pada molase dapat meniadakan efek biotin.

Perlakuan penambahan penisilin yang menghasilkan kadar asam glutamat yang paling tinggi adalah perlakuan penambahan penisilin 18 jam inkubasi, walaupun menurut analisis statistik tidak signifikan dengan perlakuan waktu penambahan penisilin yang lain. Hal ini disebabkan data yang dihasilkan pada setiap ulangan pada perlakukan yang sama kurang homogen.

\section{Kesimpulan}

Berdasarkan hasil penelitian fase logaritmik Corynebacterium glutamicum pada sistem kultur sekali unduh terjadi pada waktu inkubasi jam ke-2 sampai jam ke -22, Penisilin mampu meningkatkan produksi asam glutamat apabila dibandingkan dengan kontrol dan waktu penambahan penisilin yang tepat untuk menghasilkan kadar asam glutamat maksimum, yaitu $154319,60 \mu \mathrm{g} / \mathrm{ml}$, adalah pada waktu inkubasi jam ke-18.

\section{Ucapan Terima Kasih}

Penelitian ini dapat terlaksana atas bantuan teknis dari Sri Lestari dan Alb. Agus Adiriyanto dan bantuan pendanaan dari Universitas Atma Jaya Yogyakarta.

\section{Daftar Pustaka}

Blanch, H.W., Stephen, D. and Daniel, I.C.W. 1985, Comprehensive Biotechnology. The Principles, Applications and Regulation Of Biotechnology In Industry, Agriculture and Medicine, Volume 3, Pergamon Press, UK.

Breed, R.S., Murray, E.G.D. and Nathan, R.S. 1957, Bergey's Manual of Determinative Bacteriology, The Williams and Wilkins Company, USA.

Crueger, W. and Crueger, A. 1990. Biotechnology, A Textbook of Inustrial Microbiology, Sinauer Associates Inc., Sunderland.

Hoischen, C. And Kramer, R. 1990. Membrane alteration is necessary but not sufficient for effective glutamat secretion in Corynebacterium glutamicum. J. Bacteriol. 172: 34093416

Hong, K.T., Sun H. P., Jae, H.L., Cha, Y.C. and Jong, C.B. 1984. Control of Sugar Feeding For Glutamic Acid Fermentation, J. Ferment. Technol. 49-54.

Jutono, Joedoro, S., Hartadi, S., Kabirun, Suhadi dan Susanto, 1980, Pedoman Praktikum Mikrobiologi Umum untuk Perguruan Tinggi, Departemen Mikrobiologi Fakultas Pertanian UGM, Yogyakarta.

Kartika, B. 1990, Petunjuk Evaluasi Produk Industri Hasil Pertanian, PAU Pangan dan Gizi UGM, Yogyakarta.

Kitano, K., Sugiyama, Y. and Kanzaki, T. 1972. LGlutamate fermentation with acetic acid by an oleic acid reguiring mutant II. Inhibitory factors against the extracellular accumulation of L-glutamate. J. Ferment. Technol. 50:182191

Madigan, M.T., John M.M. and Jack, P. 2000, Brock Biology of Microorganism, $9^{\text {th }}$ ed., Prentice Hall Internationa Inc., Usa. 
Nakao, Y., Kikuchi, M., Suzuki, M. and Doi, M. 1972. Microbial production of L-glutamic acid by glycerol auxotrophs.I. Induction of glycerol auxotrophs and production of L-glutamic acid from n-paraffins. Agric.Biol.Chem. 36:490496

Nunheimer, T.D., Birnbaum, J., Ihnen, E.D. and Demain, A.L. 1970. Product Inhibition of fermentative formation of glutamic acid. Appl. Microbiol. 20:215-217

Prescott, S.C. and Dunn, C.G. 1959, Industrial Microbiology, Hill Book Company Inc.m New York, Toronto.

Schlegel, H.G. and Karin, S. 1994, Mikrobiologi Umum, Gadjah Mada University Press, Yogyakarta.

Shiio, I., Otsuka, S.I. and Katsuya, M. 1962. Effect of biotin on the bacterial formation of glutamic acid. II. Glutamate formation and cellular permeability of amino acid. J. Biochem. 51:56-62
Stryer, L. 1995. Biochemistry, $4^{\text {th }}$ ed., W.H. Freeman and Company, New York.

Takinami, K., Yoshii, H., Tsuri, H. and Okada, H. 1965. Biochemical effects of fatty acid and its derivatives on glutamic acid fermentation. III. Biotin-tween 60 relationship in the accumulation of L-glutamic acid and the growth of Brevibacterium lactofermentum. Agric. Biol.Chem. 29:351-359

Tortora, G.J, Funke, B.R. and Case, C.L. 2001 Microbiology, An Introduction, 7th.ed. Addison Wesley Longman, Inc, Toronto.

Wibowo, D., 1989, Biokimia Proses Fermentasi, PAU Pangan dan Gizi UGM, Yogyakarta.

Winarno, F.G. dan Srikandi Fardiaz, 1979, Biofermentasi dan Biosintesa Protein, Penerbit Angkasa, Bandung.

Zar, J. H. 1996. Biostatistical Analysis, 3rd.ed., PrenticeHall International, Inc., New Jersey 